\title{
Comparative characteristic of the brain natriuretic peptide and angiotensin II expression index in the structure of locus coeruleus of brain stem in rats with arterial hypertension of various origins
}

\author{
M. V. Danukalo*A-D , O. V. HanchevaF, Ye. V. Kadzharian ${ }^{\mathrm{B}, C, E}$ \\ Zaporizhzhia State Medical University, Ukraine
}

A - research concept and design; B - collection and/or assembly of data; C - data analysis and interpretation; D - writing the article; $\mathrm{E}$ - critical revision of the article; $\mathrm{F}$ - final approval of the article

Key words: brain natriuretic peptide, angiotensin II, locus coeruleus, brain stem, arterial hypertension, rats.

Pathologia 2019; 16 (2), 182-187 DOl: 10.14739/2310-1237. 2019.2.177117

*E-mail: danukalo@zsmu.pp.ua
The aim of our study was to determine the characteristics of the BNP and AT II expression in the LC structure of rat brain stem with experimental (genetically determined essential and secondary endocrine-salt) arterial hypertension and to give a comparative description of the expression pattern of these peptides in etiologically different types of arterial hypertension.

Materials and methods. The study was carried out on adult 30 male rats. 20 Wistar animals were divided into two groups control (10 rats) and 10 rats with simulated endocrine-salt $\mathrm{AH}$ (ESAH) and 10 rats of SHR line with essential AH (EAH). The expression parameters of neuropeptides, such as the content, concentration, and relative area of the immunoreactive material, were studied using an immunohistochemical method.

Results. It was found that from all BNP expression parameters in the locus coeruleus structure, only relative area increased significantly in both groups. The concentration did not significantly change, and the content of immunoreactive material increased significantly only in animals with ESAH. At the same time, all parameters of angiotensin II expression increased significantly in both experimental groups. Thus, in rats with experimental arterial hypertension in the locus coeruleus structure, more pronounced changes in expression parameters are characteristic for angiotensin II, rather than for BNP. There is a discrepancy between levels of pressor angiotensin II expression and depressor BNP expression in the direction of angiotensin II expression increasing during the arterial hypertension formation. The nature and peculiarities of these neuropeptides expression in the LC structure depend on the key link of the pathogenesis of the modeled arterial hypertension.

Conclusions. In rats of the control group with normal blood pressure in LC structure, AT II is more represented. The content and concentration of IRM to AT II are 2.32 and 2.19 times higher than the corresponding BNP values. Prevalence of AT II in the LC structure of the brainstem remains even when arterial hypertension is formed, regardless of its etiology. However, the etiopathogenetic mechanisms of arterial hypertension development impose their own characteristics. In EAH, the content and concentration of AT II is higher than BNP by 4.58 and 3.59 times; in ESAH - by 2.16 and 2.83 times. In the pathogenesis of essential arterial hypertension formation an important role is played by a change in the central control of blood pressure regulation. It is characterized by a significant predominance of the pressor component AT II over the depressor BNP in the brainstem LC structure.
Киючові слова:

мозковий

натрійуретичний

пептиА,

ангіотензин II,

locus coeruleus,

стовбур мозку,

артеріальна

гіпертензія, щури.

Патологія. - 2019. -

T. 16, № 2(46). -

C. $182-187$
Порівняльна характеристика показників експресії мозкового натрійуретичного пептиду та ангіотензину II у структурі блакитної плями стовбура мозку щурів при артеріальній гіпертензії різного ґенезу

\section{М. В. Аанукало, О. В. Ганчева, Є. В. Каджарян}

Мета роботи - встановити особливості показників експресії мозкового натрійуретичного пептиду (BNP) та ангіотензину II (AT II) у структурі блакитної плями (БП) стовбура мозку щурів з експериментальними (генетично детермінованою есенціальною та вторинною ендокринно-сольовою) артеріальними гіпертензіями (АГ), дати порівняльну характеристику паттерна експресії цих пептидів при етіологічно різних видах артеріальної гіпертензії.

Матеріали та методи. Дослідження виконали на 30 статевозрілих щурах-самцях, серед них - 20 тварин лінії Wistar, яких поділили на дві групи: 10 - контроль, 10 - зі змодельованою ендокринно-сольовою АГ (ЕСАГ); 10 щурів лінії SHR з есенціальною АГ (ЕАГ). Параметри експресії нейропептидів: вміст, концентрацію та відносну площу імунореактивного матеріалу - досліджували за допомогою імуногістохімічного методу.

Результати. Встановили, що серед досліджуваних параметрів експресії BNP у структурі БП вірогідно в обох групах збільшилась тільки відносна площа; концентрація вірогідно не змінилася, а вміст імунореактивного матеріалу вірогідно виріс тільки у тварин з ЕСАГ. Водночас усі показники експресії ангіотензину II вірогідно збільшилися в обох експериментальних групах. Отже, в щурів з експериментальною артеріальною гіпертензією у структурі блакитної плями вираженіші зміни показників експресії були характерні для ангіотензину II, ніж для BNP. Так, при сформованій артеріальній гіпертензії спостерігали невідповідність між рівнями експресії пресорного ангіотензину II і депресорного BNP у бік збільшення експресії ангіотензину II. Характер та особливості експресії досліджуваних нейропептидів у структурі блакитної плями залежать від ключової ланки патогенезу змодельованої артеріальної гіпертензії.

Висновки. У щурів контрольної групи з нормальним артеріальним тиском у структурі блакитної плями значушо представленим є AT II, вміст і концентрація якого у 2,32 та 2,19 раза перевищує відповідні показники BNP. При сформова- 
ній артеріальній гіпертензії, незалежно від ії етіології, переважання АТ II у структурі блакитної плями стовбура мозку зберігається. Але патогенетичні механізми розвитку артеріальної гіпертензії зумовлюють свої особливості. Під час ЕАГ підвищення вмісту й концентрації АТ ІІ порівняно з ВNP становить 4,58 і 3,59 раза; при ЕСАГ - у 2,16 і 2,83 раза. У патогенезі формування есенціальної артеріальної гіпертензії важливу роль відіграють зміни центрального контура регуляції артеріального тиску, характерне суттєве переважання пресорного компонента АТ II у структурі блакитної плями стовбура мозку над депресорним BNP.

\section{Сравнительная характеристика паттерна экспрессии мозгового натрийуретического пептида и ангиотензина II в структуре голубого пятна ствола мозга крыс при артериальной гипертензии различного генеза}

\section{М. В. Аанукало, О. В. Ганчева, Е. В. Каджарян}

Цель работы - установить особенности показателей экспрессии мозгового натрийуретического пептида (BNP) и ангиотензина II (AT II) в структуре голубого пятна (ГП) ствола мозга крыс с экспериментальными (генетически детерминированной эссенциальной и вторичной эндокринно-солевой) артериальными гипертензиями (АГ), дать сравнительную характеристику паттерна экспрессии этих пептидов при этиологически разных видах артериальной гипертензии.

Материалы и методы. Исследование проведено на половозрелых 30 крысах-самцах, среди которых 20 животных линии Wistar, поделенных на 2 группы: 10 - контроль, 10 - со смоделированной эндокринно-солевой АГ (ЭСАГ); 10 крыс линии SHR с эссенциальной АГ (ЭАГ). Параметры экспрессии нейропептидов: содержание, концентрацию и относительную площадь иммунореактивного материала - исследовали с помощью иммуногистохимического метода.

Результаты. Установлено, что из исследуемых параметров экспрессии BNP в структуре голубого пятна достоверно в обеих группах увеличилась лишь площадь; концентрация достоверно не изменилась, а содержание иммунореактивного материала достоверно возросло лишь у животных с ЭСАГ. Все показатели экспрессии ангиотензина II достоверно выросли в обоих экспериментальных группах. Таким образом, у крыс с экспериментальной артериальной гипертензией в структуре голубого пятна более выраженные изменения показателей экспрессии характерны для ангиотензина II, чем для BNP. Так, при сформированной артериальной гипертензии отмечено несоответствие между уровнями экспрессии прессорного ангиотензина II и депрессорного ВNP в сторону увеличения экспрессии ангиотензина II. Характер и особенности экспрессии изучаемых нейропептидов в структуре голубого пятна зависят от ключевого звена патогенеза моделированной артериальной гипертензии.

Выводы. У крыс контрольной группы с нормальным артериальным давлением в структуре голубого пятна более представленным является AT II, содержание и концентрация которого в 2,32 и 2,19 раза превышают соответствующие показатели BNP. При сформированной артериальной гипертензии, независимо от ее этиологии, преобладание AT II в структуре голубого пятна ствола мозга сохраняется. Однако этиопатогенетические механизмы развития АГ накладывают свои особенности. При ЭАГ превышение содержания и концентрации АТ II по сравнению с BNP составляет 4,58 и 3,59 раза; при ЭСАГ - в 2,16 и 2,83 раза. В патогенезе формирования эссенциальной артериальной гипертензии важную роль играет изменение центрального контура регуляции артериального давления, характерно существенное преобладание прессорного компонента АT II в структуре голубого пятна ствола мозга над депрессорным BNP.

\section{Introduction}

It is well known that the level of blood pressure $(\mathrm{BP})$ is directly related to such indicators as cardiac output (CO) and total peripheral vascular resistance (TPVR) [1]. So, the adequacy of systemic blood pressure controlling will depend on the functional state of the mechanisms of their regulation. It is no secret that both of these indicators are under complex multi-level control of the autonomic nervous system (ANS), hormonal and humoral factors. Today, when the effects and mechanisms of blood pressure regulation by hormonal and humoral agents are well studied, the neurogenic blood pressure control is still a significant issue and arouse the interest of a large number of researchers. In this regard, the problem of studying the functional state of the ANS regulatory structures in conditions of high blood pressure, especially its sympathetic regulation link, becomes actual.

One of the key brain regulatory centers of the sympathetic nervous system (SNS) is the locus coeruleus (LC)the structure of the brain, which consists of the largest accumulation of noradrenergic neurons and serves as its main source there. In the studies of E. R. Samuels and E. Szabadi, it was shown that the functional state of LC neurons largely depends on the whole complex of neurotransmitters influence on it [2]. There are a large number of studies about the influence of the well-known "classical" neurotransmitters like acetylcholine, glutamate, GABA on the morpho-functional activity of LC noradrenergic neurons [3-5]. However, in recent years, "non-classical" neurotransmitters, substances that have the properties of both local regulatory neuropeptides and distant systemic regulators are interested by scientists. Brain natriuretic peptide (BNP) and angiotensin II (AT II) are vivid examples of such substances. According to the mechanism of action, they are physiological antagonists. BNP and AT II acting in opposite directions on the SNS neurons activity regulate the $\mathrm{CO}$ and TVPR by coordinating all links of $\mathrm{BP}$ regulation: peripheral parts of the SNS, natriuretic peptide systems and renin-angiotensin-aldosterone system $[6,7]$. But, despite the fact that the effects, localization and prevalence of these two peptides in the central nervous system are being actively studied today, the features of these neurohormones balance, the dependence of the BNP and AT II expression level from the type of experimental pathology are practically absent. Not enough information about the features of the quantitative BNP and
Ключевые слова: мозговой натрийуретический пептиА, ангиотензин II, locus coeruleus, ство^ мозга, артериальная гипертензия, крысы.

Патология. - 2019. T. 16, № 2(46). C. 182-187 
AT II content in the LC structure in etiologically different types of arterial hypertension.

\section{The aim}

To determine the characteristics of the BNP and AT II expression in the LC structure of rat brain stem with experimental (genetically determined essential and secondary endocrine-salt) arterial hypertension and to give a comparative description of the expression pattern of these peptides in etiologically different types of arterial hypertension.

\section{Materials and methods}

The study was carried out on 20 adult Wistar male rats and 10 male SHR rats weighing 250-270 g. SHR rats are generally accepted as a model of essential human hypertension $(E A H)$ [8]. The Wistar rats were divided into 2 groups of 10 animals each. The first group served as a control. The rats of the second group were modeled with endocrine-saline hypertension (ESAH), which served as a model of the secondary endocrine-associated human hypertension. ESAH was induced by intraperitoneal injection of prednisolone (twice a day for 30 days: at 7 a.m. $-2 \mathrm{mg} / \mathrm{kg}$, at 20 p.m. $-4 \mathrm{mg} / \mathrm{kg}$ ) with $5 \mathrm{ml}$ of $2.3 \%$ $\mathrm{NaCl}$ solution forced intake [9]. The AH development was confirmed by 3-times detection of persistent increase in blood pressure more than $150 / 90 \mathrm{~mm} \mathrm{Hg}$. In groups of animals, blood pressure was measured using a BP-2000 apparatus (Visitech Systems, USA) [10]. Mean blood pressure levels in the control were $110 / 75 \pm 5 \mathrm{~mm} \mathrm{Hg}$, ESAH - 155/90 $\pm 5 \mathrm{~mm} \mathrm{Hg}, \mathrm{EAH}-165 / 100 \pm 5 \mathrm{~mm} \mathrm{Hg}$. In the end of experiment, the animals were immediately sacrificed via decapitation after being anesthetized with aethaminalum-natrium at a dose of $40 \mathrm{mg} / \mathrm{kg}$ body weight intraperitoneally. The study object in experimental animals was the medulla oblongata. The experimental part of the study was carried out exactly in accordance with the National "General Ethical Principles of Animal Experimentation" (Ukraine, 2001), in agreement with the Directive 2010/63EU of the European Parliament and of the Council of September 22, 2010 on the protection of animals used for scientific purposes.

Colchicine were administered intracerebroventricularly to all groups of experimental animals, including the control group, to increase the identification of the studied neuropeptides [11].

The object of the study was the brain stem of experimental animals. The topographical identification of the brainstem LC was performed using the stereotactic atlas of the rat brain [12].

Expression of BNP and AT II was studied by an immunohistochemical method. Serial $7 \mu \mathrm{m}$ brain stem sections after preliminary histochemical processing [13] were incubated with goat IgG to BNP (1:200 dilution, Santa Cruz Biotechnology, USA), or rabbit IgG to AT II (Santa Cruz Biotechnology, USA) (dilution 1:200). Sections with applied primary antibodies were kept in polymeric fixatives at $\mathrm{T}=+4{ }^{\circ} \mathrm{C}$ for 24 hours. Then, secondary murine antibodies to goat $\lg$ (on sections with primary antibodies to BNP) and secondary murine antibodies to rabbit lgG (on sections with primary antibodies to AT II) conjugated with FITC (Santa Cruz Biotechnology, USA) $(1: 200)$. The sections were kept at $\mathrm{T}=+37^{\circ} \mathrm{C}$ for $45 \mathrm{~min}$ and covered with a mixture of glycerin / phosphate buffer $(9: 1)$.

Immunofluorescence studies of brainstem sections prepared by the above described method, were performed in the ultraviolet spectrum using a $38 \mathrm{HE}$ filter (Zeiss, Germany) on AXIOSKOP microscope through a sensitive camera AxioCam-5HRm (Zeiss, Germany). Images obtained in this way were processed interactively, with a determination of the region of interest (ROI), corresponding to a LC. In the selected ROI the relative area of the immunoreactive material (IRM) to studied neurohormones (\%), the concentration of the IRM to BNP and AT II in 1 $\mu \mathrm{m}^{2}\left(\mathrm{Uif} / \mu \mathrm{m}^{2}\right.$ ), and the IRM content (Uif) to BNP and AT II were determined. The microphotographs of the LC were processed using the image analysis program - Image J. All obtained data was processed using the programs Statistica (licensing number JPZ804I382130ARCN10-J) and Excel 7.0 (Microsoft Corp., USA). To determine the reliability of the differences in the samples studied, the Student's test ( $t$ ) and, if necessary, the Whitney-Mann criterion $(U)$ were used. Differences were considered significant for $P<0.05$ [14].

\section{Results}

As a result of conducted studies, a number of differences and features of the BNP (Fig. 1) and ATII (Fig. 2) expression in the LC structure in rats with experimental arterial hypertension, both in EAH and ESAH, were found.

As it is shown in Table 1, in both groups with experimental $\mathrm{AH}$ the indicators of BNP relative area in LC structure significantly changed. Thus in EAH group, it was higher by $6.51 \%$ and in animals with ESAH - by $6.94 \%$, in comparison with the control animals. However, there were no significant differences, when the parameter of the IRM relative area to BNP between groups with experimental AH was compared. IRM concentrations to BNP in the studied structure showed no significant differences, both in comparison with the control and in the intergroup analysis in rats with modeled $\mathrm{AH}$. As for the IRM content to BNP in the LC structure, it significantly increased by $23.17 \%$ only in the ESAH group, which led to a significant difference of this parameter between the groups of rats with ESAH and EAH becoming $28.21 \%$ higher (Table. 1).

Asomewhat different results were observed in the AT Il expression in the LC structure of rats of the experimental groups. So, analyzing the relative area of IRM distribution to AT II, its significant increase was found only in animals with ESAH. This increasing made up $5.97 \%$ compared with the control group. The differences of this parameter between the experimental groups, which was also reliable, should be noted. At the same time, in the group with ESAH, the IRM relative area to AT II was higher by $8.18 \%$ compared with the $v$ alues in the group of rats with EAH (Table 2).

The IRM concentration to AT II in the LC structure in both experimental groups was significantly higher than in the control group. Its elevations were found in animals both with EAH by $59.4 \%$, and ESAH by $26.61 \%$. Significant differences in the AT II concentration index 

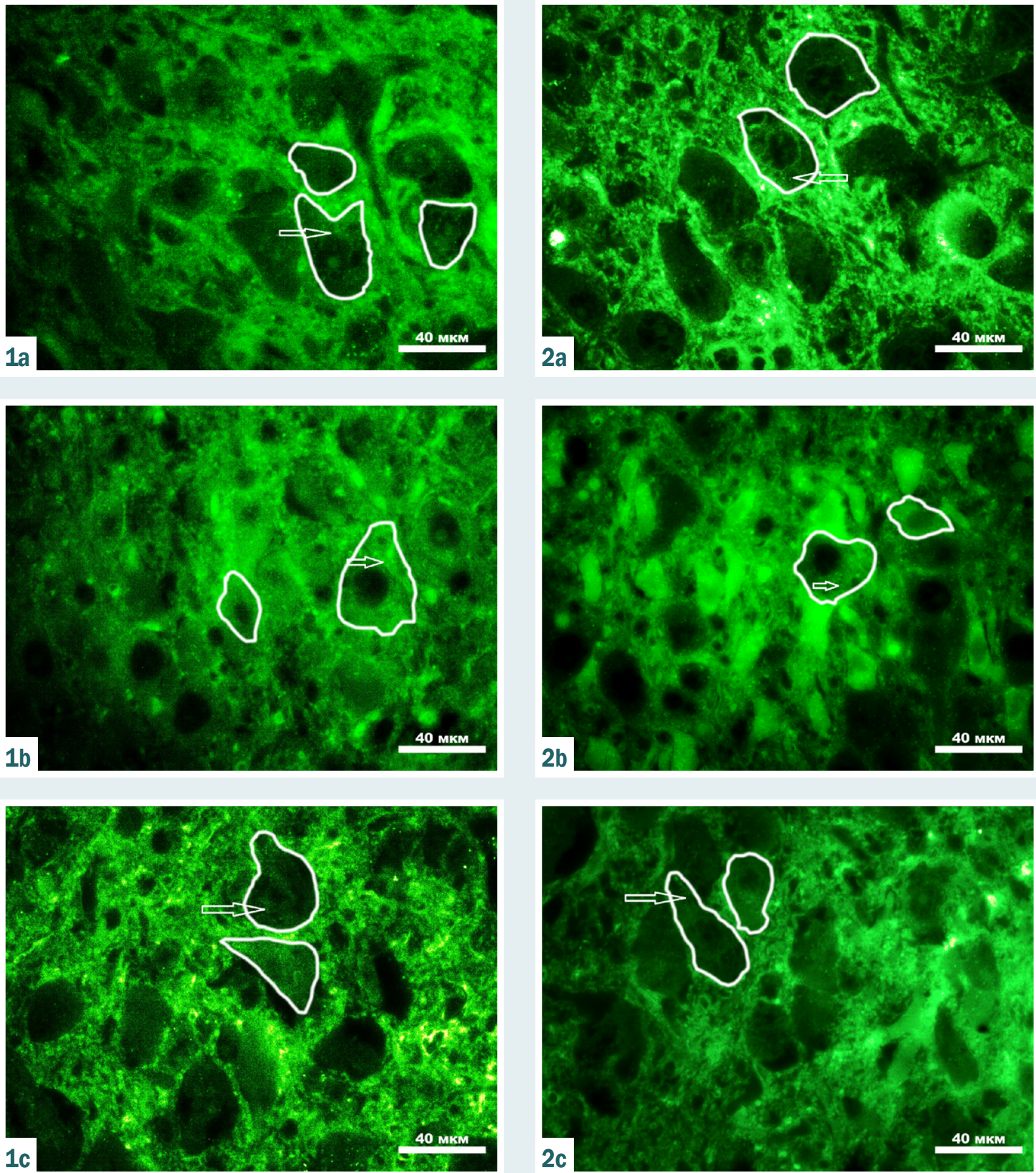

Fig. 1. BNP expression in LC structure of rat brainstem in arterial hypertension of various origin. A: control rats, B: rats with $E A H, C$ : rats with ESAH.

Fig. 2. AT II expression in LC structure of rat brainstem in arterial hypertension of various origin. A: control rats, $\mathbf{B}$ : rats with $\mathrm{EAH}, \mathrm{C}$ : rats with $\mathrm{ESAH}$.

between the experimental groups were also detected. In animals with ESAH it was lower by $20.66 \%$ than in rats with EAH. A similar result was observed in IRM content. So in the group with EAH it was higher by $89.56 \%$ than in the control, and in animals with ESAH by $38.42 \%$. At the same time, there was no significant difference between the experimental groups (Table 2).

Thus, in rats with experimental arterial hypertension in the LC structure, more pronounced changes in expression parameters are representative for AT II, rather than BNP. So, there is a discrepancy between expression levels of pressor angiotensin II and depressor BNP when arterial hypertension is formed in the direction of increasing AT II expression. It should be noted that the nature and features of studied neuropeptides expression in the LC structure depend on the key pathogenesis link of simulated arterial hypertension. The study showed that in rats with primary arterial hypertension, the pressor peptide parameters 
Table 1. Parameters of the BNP expression in the LC structure of rats with experimental arterial hypertension $(\mathrm{M} \pm \mathrm{m})$

\begin{tabular}{l|l|l|l} 
Experimental groups & IRM content (Uif) & IRM concentration & IRM relative area (\%) \\
\hline Control $(n=10)$ & $30.55 \pm 1.40$ & $6.43 \pm 0.09$ & $44.95 \pm 0.57$ \\
EAH $(n=10)$ & $29.35 \pm 1.16$ & $6.26 \pm 0.12$ & $47.88 \pm 0.82^{*}$ \\
ESAH $(n=10)$ & $37.63 \pm 1.17^{*}$ & $6.29 \pm 0.11$ & $48.07 \pm 0.52^{*}$ \\
\hline
\end{tabular}

*: indicates a significant difference in the parameters $(P<0.05)$ of the experimental group rats relative to the control; \#: indicates a reliable difference in the parameters $(\mathrm{P}<0.05)$ between rats of the experimental groups with $\mathrm{AH}$.

Table 2. Parameters of the AT II expression in the LC structure of rats with experimental arterial hypertension $(\mathrm{M} \pm \mathrm{m})$

\begin{tabular}{l|l|l|l} 
Experimental groups & IRM content (Uif) & IRM concentration & IRM relative area (\%) \\
\hline Control $(n=10)$ & $70.94 \pm 2.83$ & $14.09 \pm 0.28$ & $55.77 \pm 0.65$ \\
EAH $(n=10)$ & $134.48 \pm 12.43^{*}$ & $22.46 \pm 1.68^{*}$ & $54.63 \pm 0.91$ \\
ESAH $(n=10)$ & $98.20 \pm 2.99^{*}$ & $17.84 \pm 0.35^{*}$ & $59.1 \pm 0.65^{*}$ \\
\hline
\end{tabular}

*: indicates a significant difference in the parameters $(P<0.05)$ of the experimental group rats relative to the control; \#: indicates a reliable difference in the parameters

$(\mathrm{P}<0.05)$ between rats of the experimental groups with $\mathrm{AH}$.

significantly prevails in the LC structure, than in secondary endocrine-salt hypertension. At the same time, in endocrine-salt hypertension, increased BNP expression rates in comparison with spontaneously hypertensive animals. It may be due to the inclusion of compensation mechanisms.

\section{Discussion}

The fact of the presence of AT II and the BNP in the LC structure was shown in studies conducted in the 70s-90s years of the last century. Researchers also determined the presence of specific receptors to AT II and BNP in this structure $[6,7]$. However, the question of quantitative characteristics and the features of their content changes in the LC structure under arterial hypertension of various etiology and pathogenesis, remains poorly understood.

Considering the initially insignificant level of BNP expression in LC structure, it can be assumed that its identification in this structure is most likely related to the receipt of the peptide from other parts of the brain. According to a number of researchers, even in insignificant concentrations this neuropeptide has a sympathoinhibitory effect, thereby inhibiting the activity of SNS centers. Their hypotensive effect was demonstrated on SHR and on rats with DOXA salt hypertension. In studies on cell culture its effect by decreasing of the sympathetic neurons activity was shown $[15,16]$. BNP is believed to realize its effects through the NPR-A (natriuretic peptide receptor type $A$ ) receptors. Activation of this receptors leads to a decreasing of intracellular calcium current, which suppresses the functional activity of neurons and reduces the release of neurotransmitters [17]. Consequently, even at low concentrations, BNP can realize its inhibitory effect on the LC noradrenergic neurons of the brain stem, thereby reducing not only their functional activity, but also suppressing the tonic effect of SNS on blood pressure regulation.

Opposite to BNP, AT II has a sympathoexicatory effect, which is realized through the activation of AT1 receptors in the respective brain centers $[6,18]$. Studies have shown that in rats of the SHR line in the brain, there is a high activity of the local renin-angiotensin system, an increased content of AT II with an increased expression of its receptors $[18,19]$. This confirms the results of our studies, where a significant prevalence of AT II in the LC structure in rats of this line was established. Moreover, in rats with endocrine-salt hypertension the fact of increased AT II content in LC of the brain stem was established. Those, a high level of AT II in LC accompanies with a persistent increase in blood pressure and does not depend on the etiological nature of hypertension formation.

Considering the pathogenetic role of AT II high levels in LC of the brain stem in the arterial hypertension development, the study of $\mathrm{G}$. Huber et al. draws attention. It was demonstrated that AT II leads to the release of catecholamines from peripheral sympathetic neurons by increasing depolarization-dependent exocytosis, reducing at the same time, the reverse neuronal capture of this mediators [20]. Considering the fact, that LC is the most massive accumulation of noradrenergic neurons in the brain, an increased content of AT II in it will lead to an increasing activity of this structure. It will increase the secretion of norepinephrine and, as a result, will cause sympathoexication.

Analyzing the data of our study, we can say that in animals with experimental hypertension (primary, essential and secondary endocrine-salt) in the center of sympathetic regulation (mainly, in LC) an imbalance of pressor (AT II) and depressor (BNP) neuropeptides is observed. This is reflected in a significant prevalence of the AT II content, against the background of a slight increase in BNP. Changes in the pressor-depressor relationship in the LC structure have ethio-pathogenetic features. So in EAH (model of the SHR rat), a higher level of AT II than in the secondary ESAH was noted. It is also probably related with higher numbers of blood pressure in the SHR rats than in rats with $\mathrm{ESAH}$.

\section{Conclusions}

Based on the results of our research, we can conclude the following:

1. In rats of the control group with normal blood pressure in LC structure, AT II is more represented. The content and concentration of immunoreactive material to AT II are 2.32 and 2.19 times higher than the corresponding BNP values.

2. Prevalence of AT II in the LC structure of the brainstem remains even when arterial hypertension is formed, 
regardless of its etiology. However, the etiopathogenetic mechanisms of arterial hypertension development impose their own characteristics. In essential $\mathrm{AH}$, the content and concentration of AT II is higher than BNP by 4.58 and 3.59 times; in endocrine-salt $\mathrm{AH}-$ by 2.16 and 2.83 times.

3. In the pathogenesis of essential arterial hypertension formation an important role is played by a change in the central control of blood pressure regulation. It is characterized by a significant predominance of the pressor component AT II over the depressor BNP in the brainstem LC structure.

\section{Funding}

The study is funded as a part of scientific research work at Zaporizhzhia State Medical University: "The role of hypothalamic and brain stem peptidergic structures in the pathogenesis of arterial hypertension" (State registration number 0117U002579).

Conflicts of interest: authors have no conflict of interest to declare. Конфмікт інтересів: віАсутній.

Надійшла Ао реАакції / Received: 18.03.2019

Після Аоопрацювання / Revised: 02.04.2019

Прийнято Ао Аруку / Accepted: 04.04.2019

\section{Information about authors:}

Danukalo M. V., MD, Assistant of the Department of Pathological Physiology, Zaporizhzhia State Medical University, Ukraine. Hancheva O. V., MD, PhD, DSc, Professor, Head of the Department of Pathological Physiology, Zaporizhzhia State Medical University, Ukraine.

Kadzharian Ye. V., MD, PhD, Senior Lecturer of the Department of Pathological Physiology, Zaporizhzhia State Medical University, Ukraine.

\section{Відомості про авторів:}

Аанукало М. В., асистент каф. патологічної фізіології, Запорізький державний медичний університет, Україна. Ганчева О. В., А-р меА. наук, професор, зав. каф. патологічної фізіології, Запорізький державний медичний університет, Україна.

Каджарян Є. В., канА. меА. наук, старший викладач каф. патологічної фізіології, Запорізький державний медичний університет, Україна.

\section{Сведения об авторах:}

Аанукало М. В., ассистент каф. патологической физиологии,

Запорожский госуАарственный меАицинский университет, Украина.

Ганчева О. В., А-р меА. наук, профессор,

зав. каф. патологической физиологии, Запорожский государственный медицинский университет, Украина. КаАжарян Е. В., канА. меА. наук, старший преподаватель каф. патологической физиологии, Запорожский государственный медицинский университет, Украина.

\section{References}

[1] Johnson, A., Zhang, Z., Clayton, S., Beltz, T., Hurley, S., Thunhorst, R., \& Xue, B. (2015). The roles of sensitization and neuroplasticity in the long-term regulation of blood pressure and hypertension. American Journal Of Physiology-Regulatory, Integrative And Comparative Physiology, 309(11), R1309-R1325. doi: 10.1152/ajpregu.00037.2015

[2] Samuels, E., \& Szabadi, E. (2008). Functional Neuroanatomy of the Noradrenergic Locus Coeruleus: Its Roles in the Regulation of Arousal and Autonomic Function Part II: Physiological and Pharmacological Manipulations and Pathological Alterations of Locus Coeruleus Activity in Humans. Current Neuropharmacology, 6(3), 254-285. doi: $10.2174 / 157015908785777193$
[3] Berrocoso, E., Micó, J., \& Ugedo, L. (2006). In vivo effect of tramadol on locus coeruleus neurons is mediated by a2-adrenoceptors and modulated by serotonin. Neuropharmacology, 51(1), 146-153. doi: 10.1016/j. neuropharm.2006.03.013

[4] Chen, C., Yang, Y., \& Chiu, T. (1999). Activation of rat locus coeruleus neuron GABAA receptors by propofol and its potentiation by pentobarbital or alphaxalone. European Journal Of Pharmacology, 386(2-3), 201-210. doi: 10.1016/s0014-2999(99)00750-5

[5] Grillon, C., Cordova, J., Levine, L., \& Morgan, III, C. (2003). Anxiolytic effects of a novel group II metabotropic glutamate receptor agonist (LY354740) in the fear-potentiated startle paradigm in humans. Psychopharmacology, 168(4), 446-454. doi: 10.1007/s00213-003-1444-8

[6] McKinley, M., Albiston, A., Allen, A., Mathai, M., May, C., McAllen, R. et al. (2003). The brain renin-angiotensin system: location and physiological roles. The International Journal Of Biochemistry \& Cell Biology, 35(6), 901-918. doi: 10.1016/s1357-2725(02)00306-0

[7] Hodes, A., \& Lichtstein, D. (2014). Natriuretic Hormones in Brain Function. Frontiers In Endocrinology, 5. doi: 10.3389/fendo.2014.00201

[8] Kuzio, N. V., Tishchenko, S. V., Samojlenko, N. Yu., \& Nifontova, V. V. (2014). Analiz patofiziologicheskikh modelej arterial'noj gipertenzii u melkikh laboratornykh zhivotnykh [Analysis of pathophysiological models of arterial hypertension in small laboratory animals]. Aktualni problemy suchasnoi medytsyny. Visnyk Ukrainskoi medychnoi stomatolohichnoi akademii, 14(3), 210-213. [in Russian].

[9] Kolesnyk, Y., Hancheva, O., Abramov, A., Ivanenko, T., Tischenko, S. Kuzo, N. (patentee) (2015) Patent Ukrainy 102234. Sposib modeliuvannia symptomatychnoi arterialnoi hypertezii u dribnykh hryzuniv [Ukraine patent 102234. Method of simulation of symptomatic arterial hypertension in small rodents]. [in Ukrainian].

[10] Kolesnyk, Yu. M., Hancheva, O. V., Abramov, A. V., Kolesnyk, M. Yu., Ivanenko, T. V., Tishchenko, S. V., et al. (2017). Sovremennye podkhody i novye metodicheskie vozmozhnosti v ocenke funkcional'nogo sostoyaniya melkikh laboratornykh zhivotnykh [Modern approaches and new methodological possibilities in the functional state of small laboratory animals assessing]. Pathologia, 3(41), 364-370. doi: 10.14739/23101237.2017.3.118770 [in Russian].

[11] Norstrom, A., Hansson, H., \& Sjostrand, J. (1971). Effects of colchicine on axonal transport and ultrastructure of the hypothalamo-neurohypophyseal system of the rat. Zeitschrift FoR Zellforschung Und Mikroskopische Anatomie, 113(2), 271-293. doi: 10.1007/bf00339421

[12] Paxinos, G., \& Watson, C. H. (1986). Atlas of the rat brain in stereotaxic coordinates. Academic, New York.

[13] Pirs, E (1962). Histokhimiya. Toreticheskaya i prikladnaya [Histochemistry: Theoretical and Applied]. Moscow: Izdatel'stvo inostrannoj literatyry. [in Russian].

[14] Zajcev, V., \& Liflyandskii, V. (2003). Prikladnaya medicinskaya statistika [Applied medical statistics]. Saint-Petersburg: Foliant. [in Russian].

[15] Liu, K., Lu, C., Li, D., \& Paterson, D. (2015). Effect of B-type natriuretic peptide and phosphodiesterase $2 \mathrm{~A}$ is coupled to neurotransmitter release in pro-hypertensive rats. Autonomic Neuroscience, 192, 69-70. doi: 10.1016/j.autneu.2015.07.053

[16] Stepniakowski, K., Budzikowski, A., Lon, S., \& Szczepanska-Sadowska, E. (1991). Central ANP attenuates pressor responses to central AVP in WKY and SHR. Brain Research Bulletin, 27(2), 247-249. doi: 10.1016/0361-9230(91)90076-v

[17] Cao, L., \& Yang, X. (2008). Natriuretic peptides and their receptors in the central nervous system. Progress in Neurobiology, 84(3), 234-248. doi: 10.1016/j.pneurobio.2007.12.003

[18] Nassar, N., \& Abdel-Rahman, A. (2015). Brain stem adenosine receptors modulate centrally mediated hypotensive responses in conscious rats: A review. Journal of Advanced Research, 6(3), 331-340. doi: 10.1016/j.jare.2014.12.005

[19] Paterson, D. (2015). Cyclic nucleotides and the neural control of cardiac excitability in cardiovascular disease. Autonomic Neuroscience, 192, 45. doi: 10.1016/i.autneu.2015.07.393

[20] Huber, G., Schuster, F., \& Raasch, W. (2017). Brain renin-angiotensin system in the pathophysiology of cardiovascular diseases. Pharmacological Research, 125, 72-90. doi: 10.1016/j.phrs.2017.06.016 